\title{
Ornitologická sbírka otce a syna Václavů Tichých: zásadní přírůstek Národního muzea
}

\author{
Jan Hušek \\ Národní muzeum, Zoologické oddělení, Cirkusová 1740, 19300 Praha 9; jan.husek@nm.cz
}

Hušek J., 2020: Ornitologická sbírka otce a syna Václavů Tichých: zásadní prírůstek Národního muzea. Journal of the National Museum (Prague), Natural History Series 189: 173-176.

Pro dlouhodobé uložení v muzejních sbírkách se z uhynulých ptáků vyrábí dermoplastické vycpaniny, kožky, nebo jsou konzervovány jen některé části ptačího těla. Tím je zajištován základní piliŕ muzejnictví - uchování dokladových exemplářo pro vědecké a výstavní účely. Nové přírůstky do ornitologické sbírky Př́rodovědeckého muzea Národního muzea (dále jen PM) pocházejí v současné době především z uhynulých jedinců ze zoologických zahrad a záchranných stanic hendikepovaných živočichů. Přestože tyto exempláře hrají nepostradatelnou roli výstavních exponátů a uplatňují se při vědeckém studiu fylogenetických vztahů, jejich využitelnost pro studium dlouhodobých změn ve volné př́rodě je omezená. Ze zoologických zahrad i záchranných stanic je získáván pouze omezený počet druhů. Navíc se v př́padě exemplářủ ze ZOO jedná o jedince chované v zajetí.

Již jen zř́́dka jsou přírůstky ornitologické sbírky PM př́mým či vedlejším produktem vědeckých či sběratelských aktivit. Zřejmě nenávratně pryč je zlatá éra expedic, ze kterých se badatelé vraceli s plnými hrstmi popsaných i nepopsaných ptáků. $S$ údivem si připomínáme vskutku průkopnické sběratelské aktivity Dr. Emila Holuba v jižní Africe v druhé polovině 19. století (Jiroušková et al. 2008) a jeho pozděj-

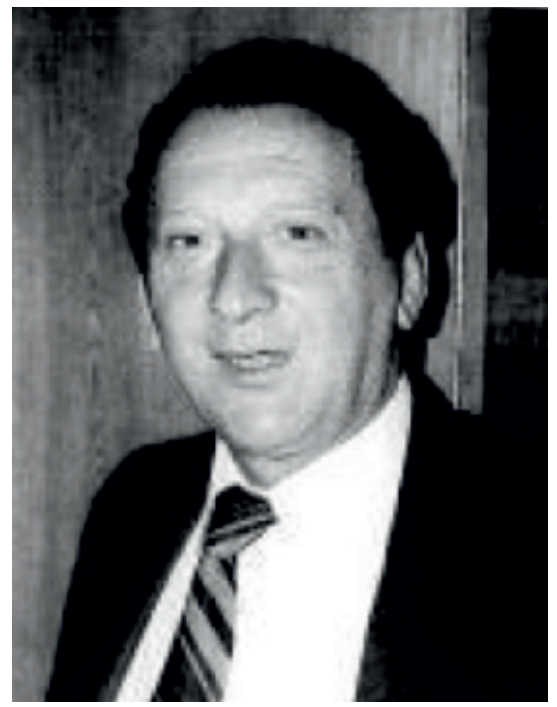

Obr. 1. Václav Tichý starší (zdroj: Kotlaba 2007). ších následovníků - Josefa Musílka na Ukrajině, Sibiři, dálném východě a v Kanadě během let 1912-1937 (Mlíkovský 2004, 2006; Mlíkovský \& Stýblo 2006), Jaroslava Boháče a Otakara Pekárka na Borneu v roce 1920 (Mlíkovský 2010), nebo Bohumila Pražana v týmu třetí Československo-Íránské entomologické expedice z roku 1977 vedené entomologem Ludvíkem Hoberlandtem (Mlíkovský 2007). 
0 to cennější je přírůstek do ornitologické sbírky PM z konce roku 2018, kdy se podařilo zakoupit jednu z posledních velkých kolekcí ptáků z území České republiky držených v soukromých rukách - systematickou sbírku ptačích vycpanin, vajec a hnízd sběratelů Ing. otce a syna Václavů Tichých. Přestože nedosahuje až epických rozměrů největší české soukromé sbírky MUDr. Alfreda Hořice, jenž Národnímu muzeu zanechal 1520 dermoplastů z období druhé poloviny 19 . století až první poloviny 20. století (Štěpánek 1946), rozšiřuje sbírka pánů Tichých úctyhodným počtem 653 dermoplastů, 443 kožek, 240 osteologických položek a 3850 snůšek s 18265 vejci stávající ornitologický sbírkový fond PM zásadní mírou.

Sbírku více jak 1200 preparovaných ptáků a okolo 20000 vajec začal budovat Ing. Václav Tichý st. (19. 6. 1928 - 5. 3. 2007), který patřil mezi výrazné postavy české ochrany přírody zejména $\mathrm{v}$ období druhé poloviny 20. století (obr. 1). Později se k tvorbě sbírky přidal i jeho syn Ing. Václav Tichý ml., který po smrti otce nakonec její značnou část prodal do PM. Sbírka dermoplastů a kožek je v muzeu uložena pod přírůstkovým číslem P6p 48/2018 a inventárním číslem P6V 122229-124034.

Sbírka vycpanin je tvořena zástupci 243 druhů z 58 čeledí (tab. 1, obr. 2). Exempláře pochází zejména z okolí Prahy a Kolínska a z jižních Čech (obr. 3, 4, 5).

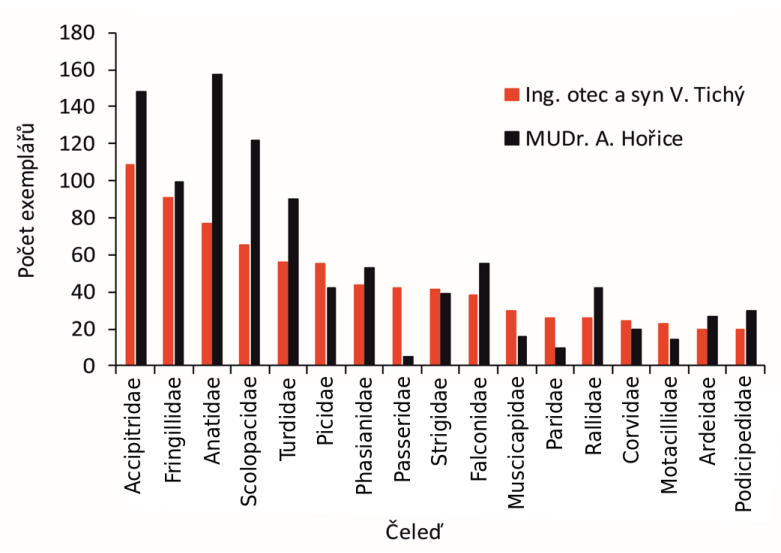

Obr. 2. Taxonomická příslušnost dermoplastů a kožek ptáků ve sbírkách Ing. otce a syna V. Tichých a MUDr. A. Hořice. Zobrazeny pouze nejpočetněji zastoupené čeledi ve sbírce $V$. Tichých s příslušnými počty exemplářů ve sbírce $A$. Hořice.

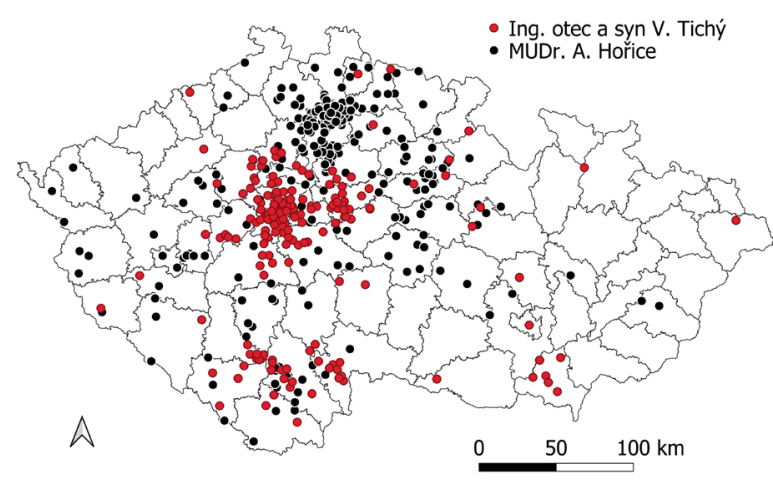

Obr. 3. Geografický původ dermoplastů a kožek ptáků ve sbírkách Ing. otce a syna V. Tichých a MUDr. A. Hořice z území České republiky.

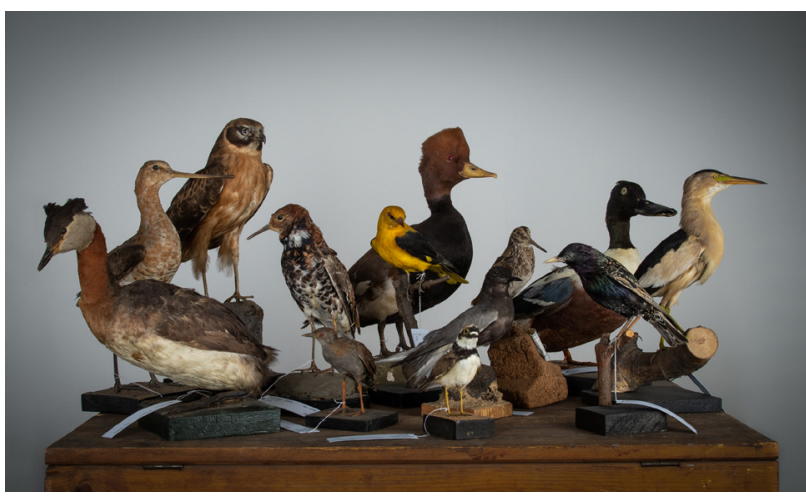

Obr. 4. Dermoplasty ptáků jižních Čech. Foto: V. Lukáš. 


\begin{tabular}{|c|c|c|c|}
\hline \multicolumn{4}{|c|}{ čeled' } \\
\hline Accipitridae & Motacillidae & Apodidae & Ciconiidae \\
\hline Fringillidae & Ardeidae & Phalacrocoracidae & Pandionidae \\
\hline Anatidae & Podicipedidae & Acrocephalidae & Remizidae \\
\hline Scolopacidae & Sylviidae & Columbidae & Sittidae \\
\hline Turdidae & Laniidae & Locustellidae & Stercorariidae \\
\hline Picidae & Hirundinidae & Oriolidae & Threskiornithidae \\
\hline Phasianidae & Bombycillidae & Aegithalidae & Coraciidae \\
\hline Passeridae & Emberizidae & Certhiidae & Gaviidae \\
\hline Strigidae & Laridae & Cuculidae & Meropidae \\
\hline Falconidae & Sturnidae & Alcedinidae & Prunellidae \\
\hline Muscicapidae & Charadriidae & Cinclidae & Alcidae \\
\hline Paridae & Tetraonidae & Sternidae & Burhinidae \\
\hline Rallidae & Alaudidae & Troglodytidae & Pteroclididae \\
\hline Corvidae & Phylloscopidae & Caprimulgidae & Recurvirostridae \\
\hline
\end{tabular}

Tab 1. Seznam čeledí ve sbírce vycpanin Ing. otce a syna V. Tichých řazený sestupně dle zastoupení.

Zahraniční původ má pouze jeden exemplár̆ ibise hnědého (Plegadis falcinellus) z května 1978 $\mathrm{z}$ okolí Burgasu v Bulharsku a jeden exemplář husy polní (Anser fabalis) z prosince 1990 z okolí Štúrova na Slovensku. V rámci čtyř nejpočetněji zastoupených čeledí pochází zástupci z čeledi Accipitridae zejména z okresu Kolín, zástupci Anatidae a Scolopacidae pak zejména z Prahy a okolí a z oblasti jihočeských rybníků a více než 90 \% všech exemplářů

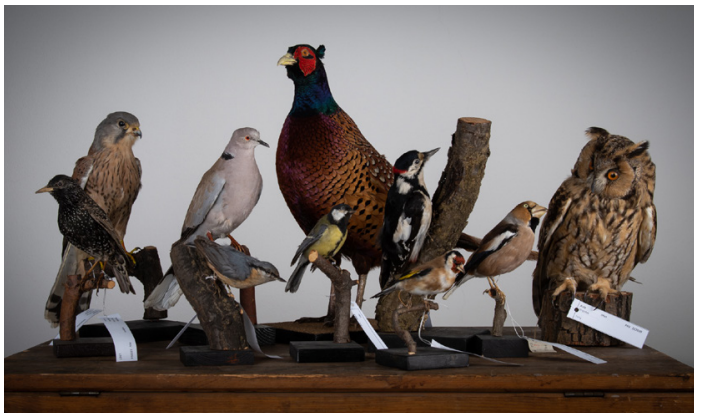

Obr. 5. Dermoplasty pražských ptáků. Foto: V. Lukáš. z čeledi Fringillidae pochází z Prahy a nejbližšího okolí. Mezi nejhojněji zastoupené druhy ve sbírce patří káně lesní Buteo buteo (44 vycpanin), vrabec domácí Passer domesticus (37), strakapoud velký Dendrocopos major (23) a bažant obecný Phasianus colchicus (22).

Datum sběru je uvedeno u $64 \%$ dermoplastů a 86 \% kožek, zatímco lokalita nálezu je známa u 64 \% dermoplastů a 78 \% kožek. Nejstarším exponátem ve sbírce je dermoplast strnada obecného (Emberiza citrinella) z roku 1888, který pochází z Křemže u Českých Budějovic. Sbírkotvorná činnost však nejintenzivněji probíhala v 50.-60. a 80. letech 20. století (obr. 6).

Hlavní devizou sbírky pánů Tichých je př́má návaznost časová (obr. 6), taxonomická (obr 2), a do značné míry geografická (obr. 3) na sbírku MUDr. Alfreda Hořice. Bez nadsázky lze konstatovat, že tam, kde Alfred Hořice skončil, otec a syn Tichý navázali. Jejich sbírka se doplňuje se sbírkou MUDr. Hořice do takové míry, že jen obě dohromady poskytují ucelený vhled do složení české avifauny v období od druhé poloviny 19. století až do přelomu milénia! Otázkou zůstává, kdo po těchto velikánech sběratelství převezme pomyslnou štafetu v budoucnosti, v době, kdy jsou ptáci pod př́snou legislativní ochranou. Lze jen doufat, že se restrikce na sběr exemplářủ ve volné prŕrodě negativně neodrazí ve schopnosti muzeí sloužit jako archiv př́rody a přední zprostředkovatel pestrosti a rozmanitosti životních forem v prostoru i čase. 


\section{Literatura}

Hudec K. \& Št’astný K. (eds.), et al. 2005: Fauna ČR. Ptáci 2/II. - Praha: Academia.

Jiroušková J., Kandert J., Mlíkovský J., Šámal M., et al., 2008: Emil Holub’s collection in the National Museum. - Praha: Národní muzeum, 204 pp.

Kotlaba F., 2007: Za ochranářem Ing. Václavem Tichým, CSc. - Depeše ČSOP 2: 21-22.

Mlíkovský J., 2004: Oologická sbírka Josefa Musílka (1885-1941) v Národním muzeu v Praze. - Panurus 14: 53-65.

Mlíkovský J., Stýblo P., 2006: Josef Musílek's collection of Asian birds in the National Museum, Praha, Czech Republic. - In: Mlíkovský J. \& Lemberk V. (eds.): Josef Musílek - český ornitolog a legionář na Sibiři: 167-176. Pardubice: Východočeské muzeum.

Mlíkovský J., 2006: Josef Musílek's collection of Canadian birds in the National Museum, Praha, Czech Republic. - In: Mlíkovský J. \& Lemberk V. (eds.): Josef Musílek - český ornitolog a legionář na Sibiři: 181-182. Pardubice: Východočeské muzeum.

Mlíkovský J., 2007: Ornithological results of the Czechoslovak-Iranian expedition in Iran in 1977. - Podoces 2: 141-142.

Mlíkovský J., 2010: Jaroslav Boháč's Borneo expedition of 1920 and its ornithological results. - Journal of the National Museum (Praha), Natural History Series 179, 1: 1-6.

Štěpánek O., 1946: Sbírka českého ptactva Dra A. Hořice. - Sylvia 8: 9.

\section{Summary}

\section{Ornithological collection of Václav Tichý and his son: a significant acquisition for the National museum}

Jan Hušek

New specimens for vertebrate museum collections are most commonly supplied by zoos and wildlife rescue stations. It is rather uncommon that large private vertebrate collections are donated or sold to natural history museums. At the end of 2018, the National Museum took advantage of a unique opportunity and purchased one of the last large privately held ornithological collections from Václav Tichý and his son. Tichý father and son collected some 653 mounted specimens and 443 bird skins of 243 species, 240 osteological items and 3850 clutches with 18265 blown eggs. The specimens represent species of various habitats, and originate largely from Central and South Bohemia. The scientific value of Tichý's collection lies in providing a solid record for the occurrence

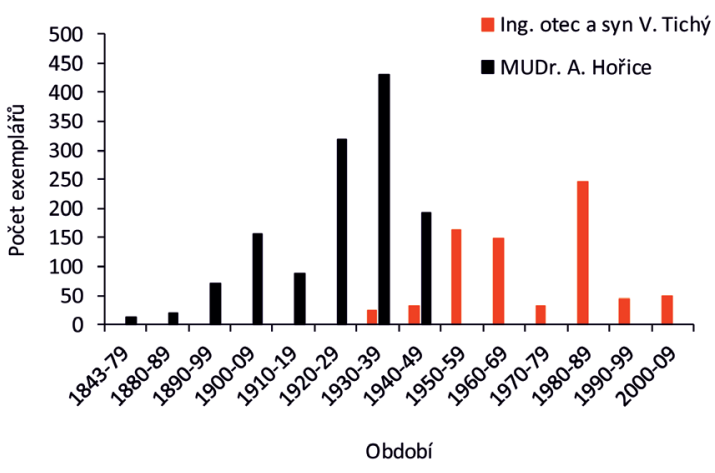

Obr. 6. Časový vývoj sbírek dermoplastů a kožek ptáků Ing. otce a syna Tichých a MUDr. Hořice z území České republiky. and composition of Czech avifauna in the second half of the 20th century. Tichý's ornithological collection can be viewed as one of the cornerstones of the Czech avifauna collection of the National Museum. 